\title{
Enriching distinctive microbial communities from marine sediments via an electrochemical-sulfide-oxidizing process on carbon electrodes
}

\author{
Shiue-Lin Li and Kenneth H. Nealson* \\ Department of Earth Science, University of Southern California, Los Angeles, CA, USA
}

Edited by:

Pravin Malla Shrestha, University of California, Berkeley, USA

\section{Reviewed by:}

Blanca Barquera, Rensselaer

Polytechnic Insitute, US Minor

Outlying Islands

Hans Karl Carlson, University of

California, Berkeley, USA

Catarina Paquete, Instituto de

Tecnologia Química e Biológica,

Portugal

\section{*Correspondence:}

Kenneth H. Nealson, Department of Earth Science, University of

Southern California, 835 Bloom

Walk, SHS562, LoS

Angeles, CA90089, USA

e-mail:knealson@usc.edu
Sulfide is a common product of marine anaerobic respiration, and a potent reactant biologically and geochemically. Here we demonstrate the impact on microbial communities with the removal of sulfide via electrochemical methods. The use of differential pulse voltammetry revealed that the oxidation of soluble sulfide was seen at $+30 \mathrm{mV}$ (vs. SHE) at all $\mathrm{pH}$ ranges tested (from $\mathrm{pH}=4$ to 8), while non-ionized sulfide, which dominated at $\mathrm{pH}=4$ was poorly oxidized via this process. Two mixed cultures (CAT and LA) were enriched from two different marine sediments (from Catalina Island, CAT; from the Port of Los Angeles, LA) in serum bottles using a seawater medium supplemented with lactate, sulfate, and yeast extract, to obtain abundant biomass. Both CAT and LA cultures were inoculated in electrochemical cells (using yeast-extractfree seawater medium as an electrolyte) equipped with carbon-felt electrodes. In both cases, when potentials of +630 or $+130 \mathrm{mV}$ (vs. SHE) were applied, currents were consistently higher at +630 then at $+130 \mathrm{mV}$, indicating more sulfide being oxidized the higher potential. In addition, higher organic-acid and sulfate conversion rates were found at $+630 \mathrm{mV}$ with CAT, while no significant differences were found with LA at different potentials. The results of microbial-community analyses revealed a decrease in diversity for both CAT and LA after electrochemical incubation. In addition, some bacteria (e.g., Clostridium and Arcobacter) not well-known to be capable of extracellular electron transfer, were found to be dominant in the electrochemical cells. Thus, even though the different mixed cultures have different tolerances for sulfide, electrochemical-sulfide removal can lead to major population changes.

Keywords: carbon electrodes, differential pulse voltammetry, electrochemical sulfide oxidation, marine sediments, microbial community analyses

\section{INTRODUCTION}

It is important to understand the abilities of microbes to interact with insoluble electron donors and acceptors when investigating the microbial communities in any specific environment. For instance, dissimilatory metal reducing bacteria (DMRB), such as Shewanella or Geobacter are capable of extracellular electron transfer (EET) to solid substrates, such as Fe(III) (Myers and Myers, 1993; Bretschger et al., 2007), or Mn(IV) (Myers and Myers, 2001; Bretschger et al., 2007), Cr(VI) (Myers et al., 2000), V(V) (Myers et al., 2004), and U(VI) (Lovley et al., 1991; Gorby and Lovley, 1992). The addition of Fe or Mn oxides will thus enrich these groups, if they are present. DMRB can also reduce electrodes and have been applied in many microbial-fuel-cell (MFC) studies (Gregory et al., 2004).

It is logical that by applying the proper potential, an electrode could be used in place of a solid-state electron donor/acceptor for metal respiring bacteria, a fact that is now well-established (Kim et al., 1999; Bond et al., 2002; Okamoto et al., 2013). However, to the best of our knowledge, no study has conclusively found that a polarized electrode will restrict the growth of microorganisms that are not capable of generating current, as long as the major growth factors are sufficiently supplied. To this end, Torres et al. (2009) demonstrated that a biofilm on an electrode surface can form an insulating layer that would unexpectedly reject truly EET-capable bacteria like Geobacter. To obtain more specific results, it is suggested that the samples should be chosen from some distinctive environments, like those with high-ionic conductivity that may possess halotolerant microorganisms being competent in MFCs.

Marine sediments are complex high-conductivity, geochemically active ecosystems of major importance in the global carbon cycle, Madigan et al. (2012). These systems are characterized by a series of redox processes with oxygen, nitrate, manganese oxide, iron oxide, and sulfate reacting in that order (Nealson and Saffarini, 1994; Burdige, 2006). Because of the very high $(\geq 25 \mathrm{mM})$ sulfate concentration, most marine sediments are dominated by sulfate reducing bacteria (SRB), and sulfide plays a crucial role in the oceanic environment (Burdige, 2006). Given these properties, and the knowledge that many bacteria are capable of EET, it is reasonable to utilize electrochemical approaches 
to study marine sediments: quantifying redox equivalents in the form of current. In addition, electrochemical removal of substrates like sulfide might also be used to reduce feedback inhibition, and facilitate the growth of other microbes on the electrode surface.

Several studies have shown that sulfide can be oxidized and ultimately deposited on the anode as element sulfur, producing current (Cooney et al., 1996; Rabaey et al., 2006; Dutta et al., 2009; Gong et al., 2013). Here, using differential pulse voltammetry (DPV) for the first time, we provide direct evidence for the oxidation of sulfide, and its role as an electron carrier. Mixed cultures obtained from the marine sediments were inoculated into an electrochemical cell and examined via chronoamperometry. In addition, microbial community analysis was used to examine the impact of sulfide removal on microbial-community composition.

\section{MATERIALS AND METHODS CHARACTERISTICS OF SEDIMENTS AND THE MIXED CULTURES}

Two sediments collected from Catalina Harbor, Santa Catalina Island $\left(33.4285^{\circ} \mathrm{N}, 118.5090^{\circ} \mathrm{W}\right)$ and the Port of Los Angeles $\left(33.7370^{\circ} \mathrm{N}, 118.2703^{\circ} \mathrm{W}\right)$ were used in this study. All the sediments were sieved by using a $420-\mu \mathrm{m}$ sieve to remove plankton, invertebrates, and gravel, as suggested elsewhere (Nielsen et al., 2010). Approximately 70 milligrams of the sieved sediments were added to $30 \mathrm{~mL}$ of modified Postgate B medium (Postgate, 1979), incubated anaerobically in serum bottles, and subsequently inoculated into electrochemical cells for further tests. The two mixed cultures from these sediment enrichments were called Catalina-Harbor (CAT) and the Port-ofLos-Angeles (LA), respectively. The organic compositions of the two different sediments were determined by the ignition method (Clesceri et al., 1989), and were 11 and $82 \mathrm{mg}$ $\mathrm{g}^{-1}$ for CAT and the LA sediments, respectively. The modified Postgate- $\mathrm{B}$ medium contained: phosphate buffer, $3.6 \mathrm{mM}$; $\mathrm{NH}_{4} \mathrm{Cl}, 18.7 \mathrm{mM} ; \mathrm{MgSO}_{4}, 16.6 \mathrm{mM} ; \mathrm{CaCl}_{2}, 450 \mu \mathrm{M}$; sodium lactate, $26 \mathrm{mM}$; ascorbic acid, $0.6 \mathrm{mM}$; thioglycolic acid, $1 \mathrm{mM}$; yeast extract, $1 \mathrm{~g} \mathrm{~L}^{-1}$; artificial seawater powder, $32 \mathrm{~g} \mathrm{~L}^{-1} ; \mathrm{FeSO}_{4}$, $1.7 \mathrm{mM}, \mathrm{C}_{6} \mathrm{H}_{9} \mathrm{NO}_{3}, 78.5 \mu \mathrm{M} ; \mathrm{MnSO}_{4}, 29.6 \mu \mathrm{M} ; \mathrm{CoCl}_{2}, 4.2 \mu \mathrm{M}$; $\mathrm{ZnCl}_{2}, 9.5 \mu \mathrm{M} ; \mathrm{CuSO}_{4}, 0.4 \mu \mathrm{M} ; \mathrm{AlK}\left(\mathrm{SO}_{4}\right)_{2}, 0.2 \mu \mathrm{M} ; \mathrm{H}_{3} \mathrm{BO}_{3}$, $1.6 \mu \mathrm{M} ; \mathrm{Na}_{2} \mathrm{MoO}_{4}, \mu \mathrm{M} ; \mathrm{NiCl}_{2}, 1.0 \mu \mathrm{M} ; \mathrm{Na}_{2} \mathrm{WO}_{4}, 0.8 \mu \mathrm{M}$. When the medium was used as an electrolyte in the electrochemical cells, the ingredients of yeast extract, ascorbic acid, and thioglycolic acid were removed, to avoid any additional electrochemical reaction on the electrode surfaces (Marsili et al., 2008; Masuda et al., 2010). In addition, the concentration of $\mathrm{FeSO}_{4}$ was reduced to $3.6 \mu \mathrm{M}$, to remove the function of impairing sulfide concentration but leave a trace amount for microbial growth. All the enrichments (including serum-bottle and electrochemical enrichements) were conducted at room temperature with initial $\mathrm{pH}=7.8$.

\section{GRAPHITE ELECTRODES, ELECTROCHEMICAL CELL, AND CHRONOAMPEROMETRIC MEASUREMENT}

In the present study, the carbon graphite electrodes (Electrolytica Inc., Amherst, NY, United States) were pretreated by soaking with a $90 \%$ ethanol followed by an acid wash with $1 \mathrm{M}$ hydrochloric acid, and dried at $105^{\circ} \mathrm{C}$. At each step, the electrodes were rinsed and washed eight times with distilled water within a sonicator, to remove the ethanol and hydrochloric acid.

An asymmetric design of electrochemical cell was used (Supplementary Figure 1), which utilizes 200-mL workingelectrode (anode) and 30-mL counter-electrode (cathode) chambers separated by $10 \mathrm{~cm}^{2}$ of a proton exchange membrane (Nafion N115, Dupont, Wilmington, DE, United States). The headspaces of the anode and cathode chambers were both continuously flushed with nitrogen gas with a flow rate of $20 \mathrm{~mL} \mathrm{~min}^{-1}$, to maintain anaerobic conditions. A metal mold with Teflon spacers was used to clamp the interface between two chambers and maintain the whole cell configuration. Each cylindrical anode chamber was configured with a cylinder inner diameter of $4.6 \mathrm{~cm}$ and a height of $17 \mathrm{~cm}$, and the inner walls was lined with $78 \mathrm{~cm}^{2}$ $(12.8 \mathrm{~cm} \times 6.1 \mathrm{~cm})$ of pretreated carbon felts fixed with a Teflon spacers. A fine platinum wire was attached outside the carbon felt as a current collector, and an $\mathrm{Ag}|\mathrm{AgCl}| \mathrm{KCl}$ (sat.) reference electrode was inserted in proximity to the carbon felt. The anode chambers were capped tightly with silicon rubber stoppers, and the liquid was mixed with a magnetic stirrer. All items except for the reference electrodes of the reactors were autoclaved at $121^{\circ} \mathrm{C}$ for $20 \mathrm{~min}$ after assembling. The whole device was connected to a potentiostat (Quadstat EA 164, eDAQ Pty. Ltd., NSW., Australia) equipped with a data acquisition system (e-corder, eDAQ Pty. Ltd., NSW., Australia), and the working electrode potential was controlled at +130 and $+630 \mathrm{mV}$ (i.e., -100 and $+400 \mathrm{mV}$ vs. $\mathrm{Ag} / \mathrm{AgCl}$, depending on the experimental conditions). All potentials in this paper are referred to the standard hydrogen electrode. The anode electrolyte consisted of the recipe described in Section Characteristics of Sediments and the Mixed Cultures; the cathode electrolyte consisted of $100 \mathrm{mM}$ of phosphate buffer $(\mathrm{pH}=7.8)$ and $80 \mathrm{mM}$ of $\mathrm{KCl}$.

\section{SULFIDE OXIDATION EXAMINED BY DIFFERENTIAL PULSE VOLTAMMETRY (DPV), CYCLIC VOLTAMMETRY (CV), AND CHOROAMPEROMETRY}

A $30-\mathrm{cm}^{3}$ glass cell connected an electrochemical analyzer (Wavenano, PINE, Grove City, PA, United States) was used to study electrochemical sulfide oxidation with the concentrations of $1.6 \mathrm{mM}$ in each tests. In DPV tests, the glassy carbon (GCE, with a diameter of $4.0 \mathrm{~mm}, \mathrm{CH}$ Instruments, Inc., USA), platinum wire (0.5 mm thick, $5 \mathrm{~cm}$ long), and $\mathrm{Ag}|\mathrm{AgCl}| \mathrm{KCl}$ (sat.) electrodes were used as the working, counter, and reference electrodes, respectively (Supplementary Figure 2A). DPV was performed using 5.0-mV pulse increments, $50-\mathrm{mV}$ pulse amplitude, $300-\mathrm{ms}$ pulse width, and a 5.0-s pulse period. Prior to implementing DPV, the GCE would was polished to a mirror-like finish with fine emery papers. In CV (with $10 \mathrm{mV} \mathrm{s}^{-1}$ of scanning rate) and chronoamperometry the graphite block $(1 \mathrm{~cm} \times 2 \mathrm{~cm} \times 0.6 \mathrm{~cm})$ connected with a platinum wire $(0.1 \mathrm{~cm}$ thick $)$ was used as a working electrode instead (Supplementary Figure 2B). To achieve different pHs, McIlvaine buffer with the amendment of $80 \mathrm{mM}$ of $\mathrm{KCl}$ was used. The concentration of thiosulfate after chronoamperometric tests were analyzed by using a cyanolysis and spectrophotometric method (Kelly et al., 1969). All the tests were run under room temperatures. 


\section{MICROBIAL COMMUNITY ANALYSES}

The deoxyribonucleic acid (DNA) was extracted using the PowerSoil DNA kit (MO BIO Laboratories, Inc., Carlsbad, CA, United States) according to the manufacturer's instructions. After each batch test, the biofilm-attaching carbon felts were cut into small pieces with an area of ca. $0.5 \times 3.0 \mathrm{~cm}^{2}$, and ca. $0.5 \mathrm{~g}$ of carbon felt was stuffed into each bead tube. To obtain an adequate DNA concentration, saline dissolved DNA extracted from five bead tubes was concentrated in one 2-mL collection tube with a spin filter, and the final DNA concentrations ranged from 20 to $70 \mu \mathrm{g} \mu \mathrm{L}^{-1}$. The $16 \mathrm{~S}$ rRNA gene $\mathrm{V} 4$ variable region PCR primers 515/806 with a barcode on the forward primer were used in a 30 cycle PCR using the HotStarTaq Plus Master Mix Kit (Qiagen, Valencia, CA, United States) under the following conditions: $94^{\circ} \mathrm{C}$ for $3 \mathrm{~min}$, followed by 28 cycles of $94^{\circ} \mathrm{C}$ for $30 \mathrm{~s}$, $53^{\circ} \mathrm{C}$ for $40 \mathrm{~s}$ and $72^{\circ} \mathrm{C}$ for $1 \mathrm{~min}$, after which a final elongation step was performed at $72^{\circ} \mathrm{C}$ for $5 \mathrm{~min}$. Multiple samples were pooled together in equal proportions based on their molecular weights and DNA concentrations. Pooled samples were purified using calibrated Ampure XP beads (Beckman Coulter Inc., Brea, CA, United States). The pooled and purified PCR product was then used to prepare a DNA library by following the Illumina TruSeq DNA library preparation protocol. Sequencing was performed at MR DNA (www.mrdnalab.com, Shallowater, TX, USA) on a MiSeq following the manufacturer's guidelines. Sequence data were processed using the Molecular Research DNA Laboratory analysis pipeline (Shallowater, TX, United States). Operational taxonomic units (OTUs) were defined by clustering at $3 \%$ divergence ( $97 \%$ similarity). Final OTUs were taxonomically classified using BLASTn against a curated database derived from GreenGenes, RDPII and NCBI [www.ncbi.nlm.nih.gov, DeSantis et al. (2006), http://rdp.cme.msu.edu].

\section{SPECIMENS PRETREATMENT AND SCANNING ELECTRONIC MICROSCOPE (SEM) OBSERVATION}

The specimens (i.e., biopellets attached on graphite felt) were fixed in a solution of $2.5 \%$ glutaraldehyde and PBS ( $\mathrm{pH} 7.8$ ) for $16 \mathrm{~h}$ at $4^{\circ} \mathrm{C}$. Specimens were rinsed three times in the PBS to remove residual glutaraldehyde, for $10 \mathrm{~min}$ each time. Dehydration was carried out with a series of gradually increasing ethanol concentrations: 50, 75, 85, 95, and 100\%. Finally, the dehydrated specimens were dried using the critical point drier (Tousimis 815, Rockville, MD, United States) and then coated with gold by an ion sputter (JEOL JFC-1100, JEOL Ltd., Tokyo, Japan). Desiccated samples were observed by using a JEOL JSM-7001 SEM (JEOL Ltd., Tokyo, Japan).

\section{INSTRUMENTAL ANALYSES}

Organic acids (i.e., lactate and acetate) contained in the cultural medium were detected using high-performance liquid chromatography (1100 Series, Agilent Technologies Inc., Santa Clara, CA, United States) equipped with a quaternary pump, a UVvisible photo diode array detector, and a reversed-phase column (Synergi $^{\mathrm{TM}} 4 \mu \mathrm{m}$ Hydro-RP $80 \AA$, Phenomenex, Torrance, CA, United States). $4.5 \mathrm{mM}$ sulfuric acid solution was used as a mobile

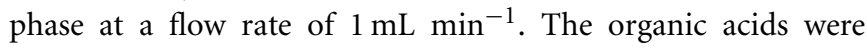
detected at a specific wavelength of $210 \mathrm{~nm}$. Concentrations of sulfate were determined using an ion chromatograph (Metrohm 850 Professional IC Anion, Herisau, Switzerland) equipped with an anion Metrosep A Supp 5-250/4.0 column operated under $40^{\circ} \mathrm{C}$. A solution containing $3.2 \mathrm{mM}$ of $\mathrm{Na}_{2} \mathrm{CO}_{3}, 1 \mathrm{mM}$ of $\mathrm{NaHCO}_{3}$, and $2.5 \%$ of acetonitrile was used as the eluent at a flow rate of $0.8 \mathrm{~mL} \mathrm{~min} \mathrm{~m}^{-1}$. Two point five $\%$ of acetonitrile was used as the regenerant which is used to regenerate the resins packed in the suppressor.

\section{RESULTS}

\section{ELECTROCHEMICAL CHARACTERISTICS OF SULFIDE OXIDATION ON THE GLASSY CARBON ELECTRODES}

Glassy carbon was used in the present study to investigate sulfide oxidation, which has been widely used in electrochemical experiments due to its uniform carbon structure (Brett and Brett, 1993). All the tests at different $\mathrm{pHs}$ were carried out by adding $1.6 \mathrm{mM}$ of sulfide, while the blank control was done in Mcllvaine buffer $(\mathrm{pH}=8)$ with no sulfide addition. As shown in Figure 1A, at $\mathrm{pH}=8$, a sulfide-oxidizing current was observed at $+30 \mathrm{mV}$, while the peak current goes to $25 \mu \mathrm{A} \mathrm{cm}{ }^{-2}$ at the potential of $+0.37 \mathrm{~V}$. From $\mathrm{pH}=8$ to 5 , the potentials where the peak current could be observed were $+370,+420,+530$, and $+590 \mathrm{mV}$,
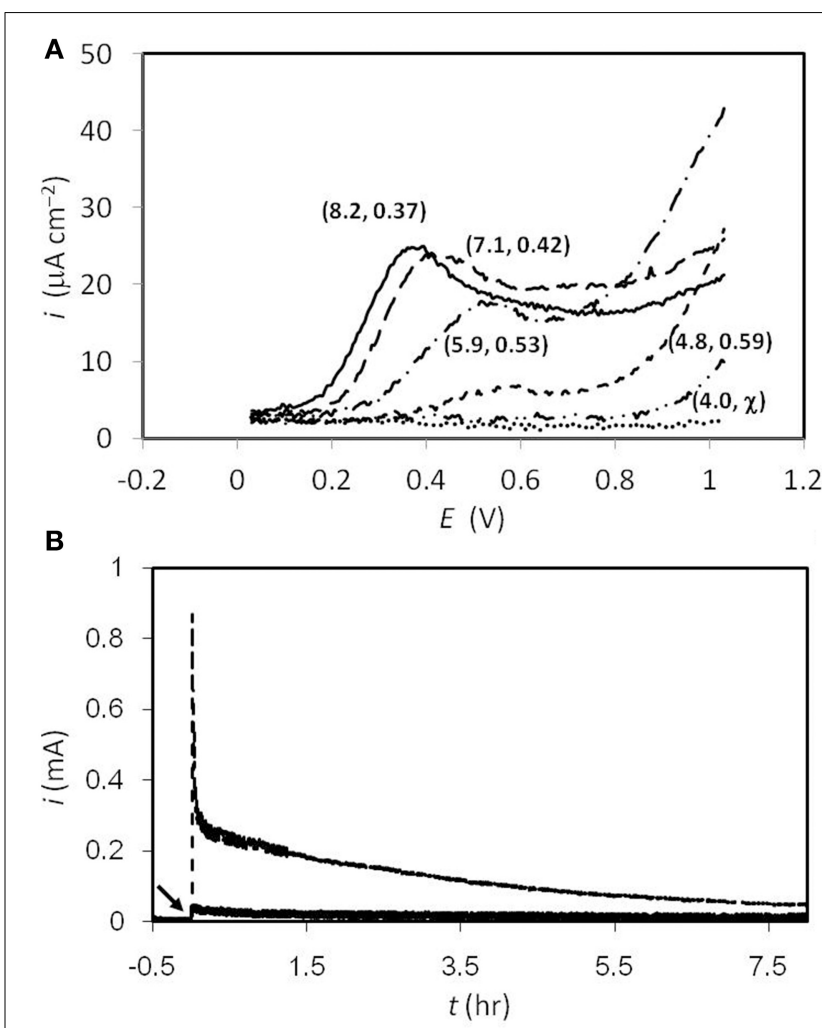

FIGURE 1 | (A) Differential pulse voltammogram of sulfide oxidation at different $\mathrm{pH}$. The numbers in the parentheses denote (actual $\mathrm{pH}$ value, peak potential). Solid line, $\mathrm{pH}$ 8; dash line, $\mathrm{pH} 7$; dash-dot line $\mathrm{pH}$ 6; short dash line, $\mathrm{pH} 5$; dash-dot-dot line, $\mathrm{pH} 4$; dot line, sulfide-free test at $\mathrm{pH} 8$. (B) Responding current during electrochemical sulfide oxidation with $630 \mathrm{mV}$ poised on the graphite electrodes. The broken and solid lines represent the results collected at $\mathrm{pH}=8$ and 4 , respectively. The arrow indicates high concentration of sulfide spiked (resulting $1.6 \mathrm{mM}$ ) at $t=0 \mathrm{hr}$. 


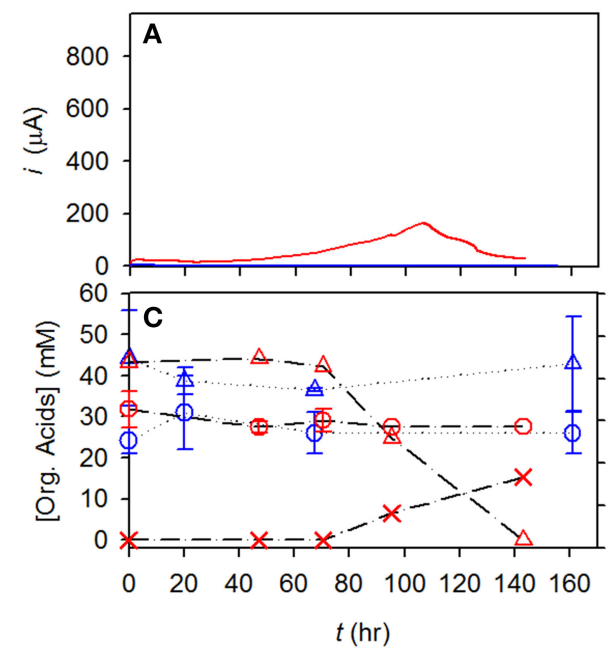

FIGURE 2 | Time course profiles of current, lactate, and acetate for CAT and LA tested in electrochemical cells. $(A, B)$ Current obtained at $+630 \mathrm{mV}$, red line; current obtained at $+130 \mathrm{mV}$, blue line; (C,D) lactate at $+630 \mathrm{mV}$, red

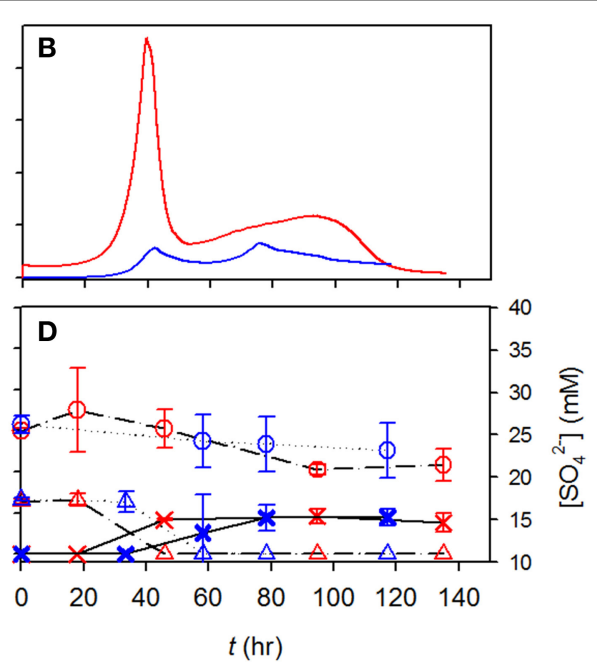

triangle; sulfate at $+630 \mathrm{mV}$, red circle; acetate at $+630 \mathrm{mV}$, red $\mathrm{X}$; lactate at $+130 \mathrm{mV}$, blue triangle; sulfate at $+130 \mathrm{mV}$, blue circle; acetate at $+130 \mathrm{mV}$, blue $\mathrm{X}$. respectively. The peak currents decreased when the $\mathrm{pH}$ decreased, while no peak current was seen at $\mathrm{pH}=4$. With regard to the result obtained at $\mathrm{pH}=8$, when the potential was scanned to higher than $900 \mathrm{mV}$, the response current kept going up, instead of decaying to the background level. Similar trends were found at all $\mathrm{pH}$ conditions. The current of the primary peak decreased when the $\mathrm{pH}$ level went lower, and no obvious primary peak was observed at $\mathrm{pH}=4$. On the other hand, the "tailing" current continued increasing at lower $\mathrm{pHs}$, indicating the occurrence of an additional reaction, and this was correlated closely to the amount of non-ionized sulfide. The continuous sulfide oxidation with $630 \mathrm{mV}$ poised was also tested abiotically, as the results exhibited in Figure 1B. After $8 \mathrm{~h}$ of reaction, 4.2 and 0.6 Coulombs of charge were collected at $\mathrm{pH}=8$ and 4 , respectively, and samples were also taken at the end of the tests for thiosulfate analyses. However, the concentrations of the thiosulfate were all beneath the detectable level $(<0.1 \mathrm{mM})$ under both conditions.

\section{CURRENT GENERATION OF SEDIMENTARY MIXED CULTURE WITH DIFFERENT POISED POTENTIALS}

As described in the Materials and Methods section, both CAT and LA sediments were used to examine the effect of electrochemical sulfide oxidation on changes in the microbial community (Figure 2). Different sizes of graphite felts, different concentrations of lactate, and different amounts of inoculation were used in these batch tests (i.e., $6 \mathrm{~mm}$ thick of graphite, $40 \mathrm{mM}$ of lactate, and $34 \mathrm{mg} \mathrm{L}^{-1}$ of inoculated volatile solids were used for the CAT test; $3 \mathrm{~mm}$ thick of graphite, $12 \mathrm{mM}$ of lactate, and $12 \mathrm{mg}$ $\mathrm{L}^{-1}$ of inoculated volatile solids were used for the LA test, respectively), to deal with the limitations of current reading due to the different levels of bio-activities. After ca. $140 \mathrm{~h}$ of incubation in the CAT test, neither lactate nor sulfate was significantly converted. At a potential of $+630 \mathrm{mV}$, lactate was not degraded until $70 \mathrm{~h}$, and subsequently decreased to zero at $140 \mathrm{~h}$, producing $20 \mathrm{mM}$ of acetate. During this time, only $1 \mathrm{mM}$ of sulfate was consumed. In the LA tests, the degradation rates of lactate were 0.62 and $0.58 \mathrm{mM} \mathrm{h}^{-1}$, with electrodes poised at +630 and $+30 \mathrm{mV}$, respectively. The final concentrations of acetate was $10 \mathrm{mM}$ in both conditions, while the sulfate concentration decreased by only $4 \mathrm{mM}$, from 25 to $21 \mathrm{mM}$.

\section{MICROBIAL COMMUNITY ANALYSES AND SEM OBSERVATION}

In addition to the reaction profiles during electrochemical incubation, microbial community analyses were carried out to compare the microbial population composition before and after electrochemical incubation. The results shown in Figures 3A,C represent the microbial communities of CAT and LA obtained after enrichment by using yeast extract containing media. Figures 3B,D,E are the results for CAT and LA enriched in the electrochemical cells with +130 and $+630 \mathrm{mV}$ applied to each condition. No microbial community analysis was done for CAT, as no significant reactions were found with $+130 \mathrm{mV}$ poised. In the serum bottle cultivated CAT, the microbial community was dominated by bacteria affiliated with Desulfovibrionales (30\%), followed by Clostridia (22\%), Tepidibacter sp. (10\%), and Clostridiaceae (16\%); The LA-containing serum bottles were dominated by Psychromonas sp. (13\%) and Clostridium sp. (13\%), followed by Desulfovibrio sp. (10\%), Bacteroidales (10\%), Clostridiaceae (9\%), Desulfobulbaceae (7\%), and Clostridia $(6 \%)$. The samples for electrochemical enrichment were taken after $140 \mathrm{~h}$ of incubation. The CAT samples maintained at $+630 \mathrm{mV}$ were dominated by Clostridium sp. (70\%), followed by Desulfovibrionales (7\%) and Clostridia (6\%). In contrast, the LA samples maintained at $130 \mathrm{mV}$ or $+630 \mathrm{mV}$ potentials were dominated by Arcobacter sp., at 74 and 55\%, respectively. From +130 to $+630 \mathrm{mV}$, the composition of Clostridium sp. was only $3 \%$ at $+130 \mathrm{mV}$, and this increased to $17 \%$ at $+630 \mathrm{mV}$, whereas the composition of Desulfovibrio sp. decreased from 17 to $10 \%$ from +130 to $+630 \mathrm{mV}$. In addition, bacteria affiliated to Ferrimonas sp. were seen only under the $+630 \mathrm{mV}$ 

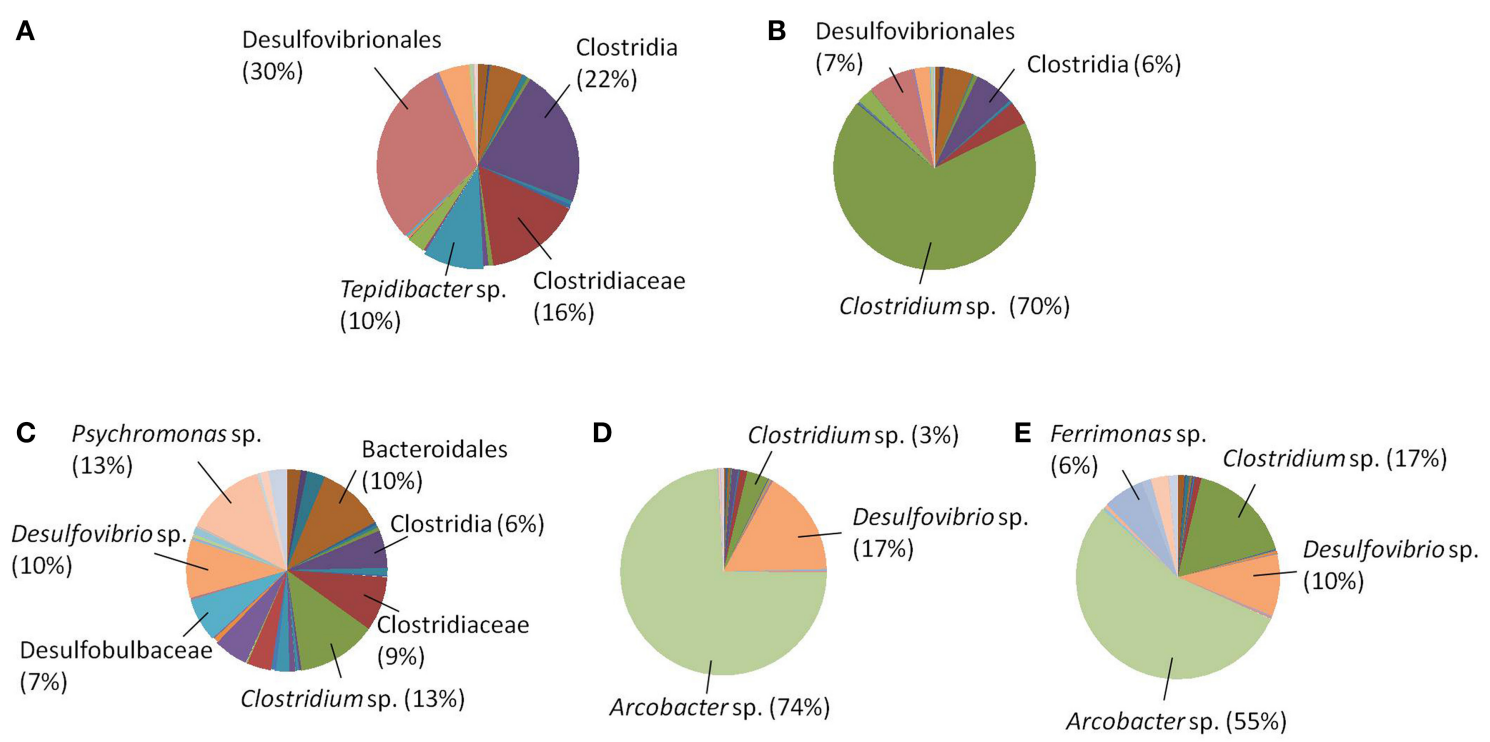

FIGURE 3 | Microbial community analyses (A) CAT in serum bottles; (B) CAT in electrochemical cells, +630 mV; (C) LA in serum bottles; (D) LA in electrochemical cells, $+130 \mathrm{mV}$; (E)LA in electrochemical cells, $+630 \mathrm{mV}$.

condition. To investigate the morphology of the mixed cultures grown on carbon felt, SEM observations were conducted after $180 \mathrm{~h}$ of electrochemical culturing (Figure 4). The SEM micrographs in Figures 4A,B show the microorganisms growing on graphite fibers with versatile morphologies, indicating that two mixed cultures were successfully cultivated on the electrode surfaces. Figures 4C,D show the nanowire-like appendages when enriching LA under the condition of $+630 \mathrm{mV}$, and this has been reported as a special microbial morphology that may possess many c-type cytochromes that can be used to facilitate EET (Gorby et al., 2006; Pirbadian et al., 2014). Besides, the sulfur crystal structure caused by sulfide oxidation that was found in Dutta et al. (2009) was not observed in the present study.

\section{DISCUSSION}

The heterotrophic microorganisms in sediments are strongly coupled to the redox processes involved with the mineralization of organics and the reduction of electron acceptors, thereby playing important roles in the global carbon cycle (Kan et al., 2011). Electrodes with poised potentials can thus be used to quantify the redox equivalents delivered to solid-state electron acceptors in the form of current. EET-capable bacteria can interact with poised electrodes, with increased swimming speeds at higher potentials (Harris et al., 2010, 2012), methods of accumulation around these electrodes, and cell growth and biofilm formation (CarmonaMartinez et al., 2013). These phenomena are all related to the interactions between bacterial cytochromes and electrode potentials, as evidenced by testing specific-gene-deletion mutants and CV. It is, thus not surprising that Ferrimonas sp., which has been reported to be closely related to Shewanella species and capable of metal respiration (Rossellomora et al., 1995; Nakagawa et al., 2006), increased in abundance upon incubation with a $+630 \mathrm{mV}$ electrode. In addition, we also suggest that Ferrimonas sp. might

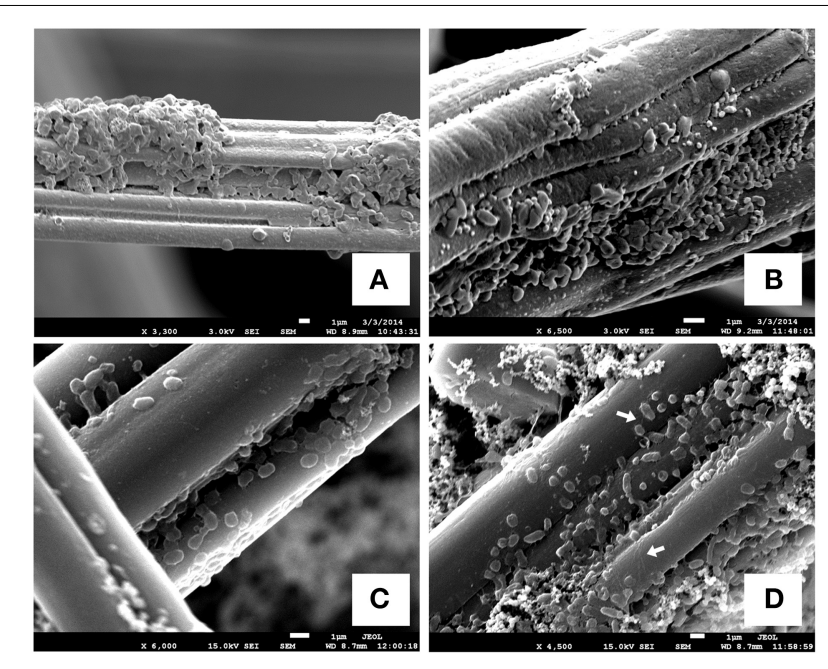

FIGURE 4 | SEM images of biofilms on graphite-felt electrodes. (A) Developed biofilms of CAT under the condition of $+630 \mathrm{mV}$; (B) developed biofilms of $L A$ under the condition of $+130 \mathrm{mV}$; (C,D) developed biofilms of $\mathrm{LA}$ under the condition of $+630 \mathrm{mV}$ that some nano-wire-like structures could be seen. The white arrows indicate the significant nanowire appendages lining on graphite fibers.

be the possible candidate to produce nanowire as shown in Figure 4, due to its capability if metal respiration. Many reports of microbial communities of heterotrophs on bio-anodes have concluded that anodes will enrich EET-capable bacteria (Torres et al., 2009; Futamata et al., 2013; Ketep et al., 2013; Babauta et al., 2014; Croese et al., 2014; Miceli et al., 2014; Zhu et al., 2014). Nevertheless, because these studies used well-defined media as electrolytes (i.e., with the buffers, substrates, conductivities, and the other growth factors at the necessary levels), the results 
cannot reveal what happens in practice in natural environments. Especially, for example, the composition of seawater is extremely complicated, and thus some additional reactions might biotically or abiotically occur on the electrodes [e.g., element sulfur deposition (Dutta et al., 2009), and iron-sulfide might form, Nakamura et al. (2010)], thus creating some other electron transfer mechanisms instead of, or in addition to, the cytochrome-mediated ones. Therefore, we suggest that prior to any in situ applications (Friedman et al., 2012), the surroundings of the electrodes should be thoroughly investigated to understand the contributions of background abiotic currents. Exactly how this should be done needs to be worked out, as experiments with sediment killed controls are difficult.

Based on our preliminary work (Supplementary Figure 3), $\mathrm{CV}$ tests were carried out to analyze the sulfide oxidation on graphite electrodes. According to the results, a significant oxidizing current started at an onset of $+30 \mathrm{mV}$. Concurrently, the peak current of ca. $1 \mathrm{~mA}$ was found at $+430 \mathrm{mV}$. The peak current decreased when increasing the CV cycles, indicating that while the sulfide readily oxidized there was no corresponding abiotic (reversible) reduction reaction within the scanning interval. This result agrees very well with a previous study (Liang et al., 2013). In addition to CV, DPV provides an efficient way to impair the nonFaradic charging current on the electrode surface, which renders the voltammogram more reliable and informative. In particular, if a small surface area $\left(\mathrm{ca} .0 .1 \mathrm{~cm}^{2}\right.$ ) electrode is used, then this can minimize interference from the non-Faradic charging current, and thus produce more accurate results. According to the results shown in Figure 1A, at all pHs the currents did not go back to the background levels as revealed in the sulfide-free test (i.e., the dotted line in Figure 1A), which implies that the sulfide could be converted to other oxidized species, rather than only to element sulfur (e.g., thiosulfate). The potential of the peak current to shift along with the change in $\mathrm{pH}$ is expected, as sulfide oxidation is associated with proton release. However, the DPV and chronoamperometry results (Figures 1A,B) indicate that the efficiency of oxidizing sulfide became worse at low $\mathrm{pH}$. This might be due to the hydrophobic characteristic of the non-ionized sulfide that forms at low $\mathrm{pH}$, which might inhibit sulfide oxidation on the electrode surface. With regard to thiosulfate analyses, the results of low amount converted $(<1 \mathrm{mM})$ are similar to the results reported by Dutta et al. (2009). In addition, the results in Figure 1B exhibit that even with a high potential poised (i.e., $630 \mathrm{mV}), 1.6 \mathrm{mM}$ of sulfide was not oxidized readily and required more than $8 \mathrm{~h}$ to be depleted. It is suggested that the sulfur chemistry on polarized electrodes could be further studied, for the sake of clarifying the mechanisms and enhancing sulfide-removal rate on anodes.

The presence of metals (e.g., iron) in culture medium is usually required to remove the sulfide produced by SRB (Widdel, 1983; Madigan et al., 2012). In addition, the low level of sulfide (ca. $0.6-3 \mathrm{mM}$ ) generated by SRBs also inhibits other microorganisms with regard to developing consortia [e.g., anaerobic digestor, Speece (1983) and Parkin et al. (1990), and marine bacteria (Mirzoyan and Schreier, 2014)], which can present problems when trying to study microbial consortia including SRBs. However, some SRBs can tolerate sulfide concentrations of up to $16 \mathrm{mM}$ (Reis et al., 1992) which is higher than the previously reported level. In the present study, sulfide oxidation is similar to removing inhibitors for the other microorganisms that are not SRBs. Therefore, the abundance of SRB in the CAT or LA cultures did not significantly increase after electrochemical enrichment (i.e., from 30 to $7 \%$ for Desulfovibrionales in CAT; from 10 to $17 \%$ or $10 \%$ for Desulfovibrio sp. in LA). It is noteworthy that, the amount of volatile solids in the sediment of Port of Los Angeles is much greater than that in the sediment of Catalina Harbor (shown in Section Characteristics of Sediments and the Mixed Cultures). This implies that a higher level of heterotrophicsulfate-reducing activity might be driven by the organic-rich environment in the sediment of the Port of Los Angeles, resulting in a considerable amount of sulfide generated in situ, and enabling the indigenous microorganisms to tolerate higher levels of this. This could explain why the tendency of lactate degradation does not change significantly when enriching LA electrochemically, no matter whether +30 or $+630 \mathrm{mV}$ of potentials is applied.

According to the results obtained after the electrochemical enrichment, some bacteria which are not EET-capable, like Clostridium sp. and Arcobacter sp., became dominant in CAT and LA, respectively. Clostridium species have been reported as the dominant populations on polarized graphite electrodes in many studies (Rismani-Yazdi et al., 2007; Timmers et al., 2012; Zhang et al., 2012). However, the discussion of the their EET capabilities was not sufficiently given, but some results with regard to using coating catalysts [i. e., poly(tetrafluoroaniline), which is used to convert hydrogen produced by Clostridium sp., (Niessen et al., 2004)] were quoted incorrectly. In addition, the Arcobacter species has only been reported as an electrochemically active bacterium in a few other studies (Fedorovich et al., 2009; Pereira-Medrano et al., 2013). While the factors leading to the enrichment of any given group cannot be specified at this time, the potential of the electrode surface provides some advantages to these microbes, making them more likely to be associated with the consortia that are already there.

Electrochemical sulfide oxidation was used in the present study to remove sulfide continuously, and this process can be used to avoid the addition of confined metal when removing sulfide during continuous culture. Unlike traditional methods, because of the accumulation of sulfide, enrichments for microorganisms commonly involve a series of transfers to sulfide-free media. In contrast, using the approach proposed in this work, and continually removing sulfide, may make it possible to find and cultivate previously uncultivated microbial strains for physiological study. We believe that the use of this electrochemical approach will lead to a better understanding of how and why microorganisms exchange electrons with solid surfaces, and how this ability can be used for the cultivation, understanding, and exploitation of microbes from many different environments.

\section{ACKNOWLEDGMENTS}

The authors would like to express their gratitude for the financial support provided by the Ministry of Science and Technology (formerly National Science Council), Taiwan, R.O.C. Specifically, this research was funded by a post-doctoral grant to study abroad (NSC 101-2917-I-564-063). 


\section{SUPPLEMENTARY MATERIAL}

The Supplementary Material for this article can be found online at: http://www.frontiersin.org/journal/10.3389/fmicb.2015. 00111/abstract

\section{REFERENCES}

Babauta, J. T., Atci, E., Ha, P. T., Lindemann, S. R., Ewing, T., Call, D. R., et al. (2014). Localized electron transfer rates and microelectrode-based enrichment of microbial communities within a phototrophic microbial mat. Front. Microbiol. 5:11. doi: 10.3389/fmicb.2014.00011

Bond, D. R., Holmes, D. E., Tender, L. M., and Lovley, D. R. (2002). Electrodereducing microorganisms that harvest energy from marine sediments. Science 295, 483-485. doi: 10.1126/science.1066771

Bretschger, O., Obraztsova, A., Sturm, C. A., Chang, I. S., Gorby, Y. A., Reed, S. B. et al. (2007). Current production and metal oxide reduction by Shewanella oneidensis MR-1 wild type and mutants. Appl. Environ. Microbiol. 73, 7003-7012. doi: 10.1128/AEM.01087-07

Brett, C. M. A., and Brett, A. M. O. (1993). Electrochemistry: Principles, Methods, and Applications. Oxford: Oxford Uniersity Press.

Burdige, D. J. (2006). Geochemistry of Marine Sediments. Princeton, NJ: Princeton University Press.

Carmona-Martinez, A. A., Harnisch, F., Kuhlicke, U., Neu, T. R., and Schroeder, U. (2013). Electron transfer and biofilm formation of Shewanella putrefaciens as function of anode potential. Bioelectrochemistry 9, 23-29. doi: 10.1016/j.bioelechem.2012.05.002

Clesceri, L. S., Greenberg, A. E., and Trussell, R. R. (eds.). (1989). Standard Methods for the Examination of Water and Wastewater, 17th Edn. Washington, DC: American Public Health Association.

Cooney, M. J., Roschi, E., Marison, I. W., Comninellis, C., and von Stockar, U. (1996). Physiologic studies with the sulfate-reducing bacterium Desulfovibrio desulfuricans: evaluation for use in a biofuel cell. Enz. Microb. Technol. 18, 358-365.

Croese, E., Jeremiasse, A. W., Marshall, I. P. G., Spormann, A. M., Euveritik, G.-J. W., Geelhoed, J. S., et al. (2014). Influence of setup and carbon source on the bacterial community of biocathodes in microbial electrolysis cells. Enz. Microb. Technol. 61-62, 67-75. doi: 10.1016/j.enzmictec.2014.04.019

DeSantis, T. Z., Hugenholtz, P., Keller, K., Brodie, E. L., Larsen, N., Piceno, Y. M., et al. (2006). NAST: a multiple sequence alignment server for comparative analysis of 16S rRNA genes. Nucleic Acids Res. 34, W394-W399. doi: 10.1093/nar/gkl244

Dutta, P. K., Keller, J., Yuan, Z., Rozendal, R. A., and Rabaey, K. (2009). Role of sulfur during acetate oxidation in biological anodes. Environ. Sci. Technol. 43, 3839-3845. doi: 10.1021/es803682k

Fedorovich, V., Knighton, M. C., Pagaling, E., Ward, F. B., Free, A., and Goryanin, I. (2009). Novel electrochemically active bacterium phylogenetically related to Arcobacter butzleri, isolated from a microbial fuel cell. Appl. Environ. Microbiol. 75, 7326-7334. doi: 10.1128/AEM.01345-09

Friedman, E. S., Rosenbaum, M. A., Lee, A. W., Lipson, D. A., Land, B. R., and Angenent, L. T. (2012). A cost-effective and field-ready potentiostat that poises subsurface electrodes to monitor bacterial respiration. Biosen. Bioelectron. 32 , 309-313. doi: 10.1016/j.bios.2011.12.013

Futamata, H., Bretschger, O., Cheung, A., Kan, J., Owen, R., and Nealson, K. H. (2013). Adaptation of soil microbes during establishment of microbial fuel cell consortium fed with lactate. J. Biosci. Bioeng. 115, 58-63. doi: 10.1016/j.jbiosc.2012.07.016

Gong, Y., Ebrahim, A., Feist, A. M., Embree, M., Zhang, T., Lovley, D., et al. (2013). Sulfide-driven microbial electrosynthesis. Environ. Sci. Technol. 47, 568-573. doi: 10.1021/es303837j

Gorby, Y. A., and Lovley, D. R. (1992). Enzymatic uranium precipitation. Environ. Sci. Technol. 26, 205-207.

Gorby, Y. A., Yanina, S., McLean, J. S., Rosso, K. M., Moyles, D., Dohnalkova, A., et al. (2006). Electrically conductive bacterial nanowires produced by Shewanella oneidensis strain MR-1 and other microorganisms. Proc. Nat. Acad. Sci. U.S.A.103, 11358-11363. doi: 10.1073/pnas.0604517103

Gregory, K. B., Bond, D. R., and Lovley, D. R. (2004). Graphite electrodes as electron donors for anaerobic respiration. Environ. Microbiol. 6, 596-604. doi: 10.1111/j.1462-2920.2004.00593.x
Harris, H. W., El-Naggar, M. Y., Bretschger, O., Ward, M. J., Romine, M. F. Obraztsova, A. Y., et al. (2010). Electrokinesis is a microbial behavior that requires extracellular electron transport. Proc. Nat. Acad. Sci. U.S.A. 107, 326-331. doi: 10.1073/pnas.0907468107

Harris, H. W., El-Naggar, M. Y., and Nealson, K. H. (2012). Shewanella oneidensis MR-1 chemotaxis proteins and electron-transport chain components essential for congregation near insoluble electron acceptors. Biochem. Soc. Trans. 40, 1167-1177. doi: 10.1042/BST20120232

Kan, J., Wang, Y., Obraztsova, A., Rosen, G., Leather, J., Scheckel, K. G., et al. (2011). Marine microbial community response to inorganic and organic sediment amendments in laboratory mesocosms. Ecotoxicol. Environ. Saf. 74, 1931-1941. doi: 10.1016/j.ecoenv.2011.06.011

Kelly, D. P., Chambers, L. A., and Trudinge, P. A. (1969). Cyanolysis and spec trophotometric estimation of trithionate in mixture with thiosulfate and tetrathionate. Anal. Chem. 41, 898-901.

Ketep, S. F., Bergel, A., Bertrand, M., Achouak, W., and Fourest, E. (2013). Sampling location of the inoculum is crucial in designing anodes for microbial fuel cells. Biochem. Engin. J. 73, 12-16. doi: 10.1016/j.bej.2013.01.001

Kim, B. H., Kim, H. J., Hyun, M. S., and Park, D. H. (1999). Direct electrode reaction of $\mathrm{Fe}(\mathrm{III})$-reducing bacterium, Shewanella putrefaciens. J. Microbiol. Biotechnol. 9, 127-131.

Liang, F. Y., Deng, H., and Zhao, F. (2013). Sulfur pollutants treatment using microbial fuel cells from perspectives of electrochemistry and microbiology. Chinese J. Anal. Chem. 41, 1133-1139. doi: 10.1016/S1872-2040(13) 60669-6

Lovley, D. R., Phillips, E. J. P., Gorby, Y. A., and Landa, E. R. (1991). Microbial reduction of uranium. Nature 350, 413-416.

Madigan, M. T., Martinko, J. M., Stahl, D. A., and Clark, D. P. (2012). Brock Biology of Microorganisms. London: Pearson Education, Inc.

Marsili, E., Rollefson, J. B., Baron, D. B., Hozalski, R. M., and Bond, D. R. (2008). Microbial biofilm voltammetry: direct electrochemical characterization of catalytic electrode-attached biofilms. Appl. Environ Microbiol. 74, 7329-7337. doi: 10.1128/AEM.00177-08

Masuda, M., Freguia, S., Wang, Y. F., Tsujimura, S., and Kano, K. (2010) Flavins contained in yeast extract are exploited for anodic electron transfer by Lactococcus lactis. Bioelectrochemistry 78, 173-175. doi: 10.1016/j.bioelechem. 2009.08.004

Miceli, J. F. III, Garcia-Pena, I., Parameswaran, P., Torres, C. I., and KrajmalnikBrown, R. (2014). Combining microbial cultures for efficient production of electricity from butyrate in a microbial electrochemical cell. Bioresour. Technol. 169, 169-174. doi: 10.1016/j.biortech.2014.06.090

Mirzoyan, N., and Schreier, H. J. (2014). Effect of sulfide on growth of marine bacteria. Arch. Microbiol. 196, 279-287. doi: 10.1007/s00203-014-0968-0

Myers, C. R., and Myers, J. M. (1993). Ferric reductase associated with the membranes of anaerobically grown Shewanella-putrefaciens MR-1. Fems Microbiol. Lett. 108, 15-22.

Myers, C. R., Carstens, B. P., Antholine, W. E., and Myers, J. M. (2000). Chromium(VI) reductase activity is associated with the cytoplasmic membrane of anaerobically grown Shewanella putrefaciens MR-1. J. Appl. Microbiol. 88, 98-106. doi: 10.1046/j.1365-2672.2000.00910.x

Myers, J. M., Antholine, W. E., and Myers, C. R. (2004). Vanadium(V) reduction by Shewanella oneidensis MR-1 requires menaquinone and cytochromes from the cytoplasmic and outer membranes. Appl. Environ. Microbiol. 70, 1405-1412. doi: 10.1128/AEM.70.3.1405-1412.2004

Myers, J. M., and Myers, C. R. (2001). Role for outer membrane cytochromes OmcA and OmcB of Shewanella putrefaciens MR-1 in reduction of manganese dioxide. Appl. Environ. Microbiol. 67, 260-269. doi: 10.1128/AEM.67.1.260269.2001

Nakagawa, T., Lino, T., Suzuki, K., and Harayama, S. (2006). Ferrimonas futtsuensis sp. nov. and Ferrimonas kyonanensis sp. nov., selenate-reducing bacteria belonging to the Gammaproteobacteria isolated from Tokyo Bay. Int. J. Syst. Evol. Microbiol. 56, 2639-2645. doi: 10.1099/ijs.0.64399-0

Nakamura, R., Okamoto, A., Tajima, N., Newton, G. J., Kai, F., Takashima, T., et al. (2010). Biological iron-monosulfide production for efficient electricity harvesting from a deep-sea metal-reducing bacterium. Chembiochem 11, 643-645. doi: 10.1002/cbic. 200900775

Nealson, K. H., and Saffarini, D. (1994). Iron and manganese in anaerobic respiration-environmental significance, physiology, and regulation. Annu. Rev. Microbiol. 48, 311-343. 
Nielsen, L. P., Risgaard-Petersen, N., Fossing, H., Christensen, P. B., and Sayama, M. (2010). Electric currents couple spatially separated biogeochemical processes in marine sediment. Nature 463, 1071-1074. doi: 10.1038/nature08790

Niessen, J., Schröder, U., and Scholz, F. (2004). Exploiting complex carbohydrates for microbial electricity generation - a bacterial fuel cell operating on starch. Electrochem. Commun. 6, 955-958. doi: 10.1016/j.elecom.2004.07.010

Okamoto, A., Hashimoto, K., Nealson, K. H., and Nakamura, R. (2013). Rate enhancement of bacterial extracellular electron transport involves bound flavin semiquinones. Proc. Natl. Acad. Sci. U.S.A. 110, 7856-7861. doi: 10.1073/pnas. 1220823110

Parkin, G. F., Lynch, N. A., Kuo, W. C., Vankeuren, E. L., and Bhattacharya, S. K. (1990). Interaction between sulfate reducers and methanogens fed acetate and propionate. Res. J. Water Pollut. Contr. Fed. 62, 780-788.

Pereira-Medrano, A. G., Knighton, M., Fowler, G. J.S., Ler, Z. Y., Trong Khoa, P., Ow, S. Y., et al. (2013). Quantitative proteomic analysis of the exoelectxogenic bacterium Arcobacter butzleri ED-1 reveals increased abundance of a flagellin protein under anaerobic growth on an insoluble electrode. J. Proteomics 78, 197-210. doi: 10.1016/j.jprot.2012.09.039

Pirbadian, S., Barchinger, S. E., Leung, K. M., Byun, H. S., Jangir, Y., Bouhenni, R. A., et al. (2014). Shewanella oneidensis MR-1 nanowires are outer membrane and periplasmic extensions of the extracellular electron transport components. Proc. Natl. Acad. Sci. U.S.A. 111, 12883-12888. doi: 10.1073/pnas.1410551111

Postgate, J. R. (1979). The Sulphate-Reducing Bacteria. London: Syndics of the Cambridge University Press.

Rabaey, K., Van de Sompel, K., Maignien, L., Boon, N., Aelterman, P., Clauwaert, P., et al. (2006). Microbial fuel cells for sulfide removal. Environ. Sci. Technol. 40, 5218-5224. doi: 10.1021/es060382u

Reis, M. A. M., Almeida, J. S., Lemos, P. C., and Carrondo, M. J. T. (1992). Effect of hydrogen-sulfide on growth of sulfate reducing bacteria. Biotechnol. Bioeng. 40, 593-600.

Rismani-Yazdi, H., Christy, A. D., Dehority, B. A., Morrison, M., Yu, Z., and Tuovinen, O. H. (2007). Electricity generation from cellulose by rumen microorganisms in microbial fuel cells. Biotechnol. Bioeng. 97, 1398-1407. doi: 10.1002/bit.21366

Rossellomora, R. A., Ludwig, W., Kampfer, P., Amann, R., and Schleifer, K. H. (1995). Ferrimonas-balearica gen-nov, spec-nov, a new marine facultative Fe (III) reducing bacterium. Syst. Appl. Microbiol. 18, 196-202. doi: 10.1016/S0723-2020(11)80390-5
Speece, R. E. (1983). Anaerobic biotechnology for industrial wastewater-treatment. Environ. Sci. Technol. 17, A416-A427.

Timmers, R. A., Rothballer, M., Strik, D. P. B. T. B., Engel, M., Schulz, S., Schloter, M., et al. (2012). Microbial community structure elucidates performance of Glyceria maxima plant microbial fuel cell. Appl. Microbiol. Biotechnol. 94, 537-548. doi: 10.1007/s00253-012-3894-6

Torres, C. I., Krajmalnik-Brown, R., Parameswaran, P., Marcus, A. K., Wanger, G., Gorby, Y. A., et al. (2009). Selecting anode-respiring bacteria based on anode potential: phylogenetic, electrochemical, and microscopic characterization. Environ. Sci. Technol. 43, 9519-9524. doi: 10.1021/ es902165y

Widdel, F. (1983). Methods for enrichment and pure culture isolation of filamentous gliding sulfate-reducing bacteria. Arch. Microbiol. 134, 282-285.

Zhang, G., Zhao, Q., Jiao, Y., Wang, K., Lee, D.-J., and Ren, N. (2012). Biocathode microbial fuel cell for efficient electricity recovery from dairy manure. Biosen. Bioelectron. 31, 537- 543. doi: 10.1016/j.bios.2011.11.036

Zhu, X., Yates, M. D., Hatzell, M. C., Rao, H. A., Saikaly, P. E., and Logan, B. E. (2014). Microbial community composition is unaffected by anode potential. Environ. Sci. Technol. 48, 1352-1358. doi: 10.1021/ es404690q

Conflict of Interest Statement: The authors declare that the research was conducted in the absence of any commercial or financial relationships that could be construed as a potential conflict of interest.

Received: 01 November 2014; accepted: 29 January 2015; published online: 17 February 2015.

Citation: Li S-L and Nealson KH (2015) Enriching distinctive microbial communities from marine sediments via an electrochemical-sulfide-oxidizing process on carbon electrodes. Front. Microbiol. 6:111. doi: 10.3389/fmicb.2015.00111

This article was submitted to Microbial Physiology and Metabolism, a section of the journal Frontiers in Microbiology.

Copyright (c) 2015 Li and Nealson. This is an open-access article distributed under the terms of the Creative Commons Attribution License (CC BY). The use, distribution or reproduction in other forums is permitted, provided the original author(s) or licensor are credited and that the original publication in this journal is cited, in accordance with accepted academic practice. No use, distribution or reproduction is permitted which does not comply with these terms. 